\title{
Ayotzinapa 43: The Political Aesthetics of Drone Protest Graffiti
}

\author{
Mary Louisa Cappelli \\ Department of Liberal Arts and Sciences, Nevada State College, Henderson, Nevada, USA \\ Email: mlcappelli@globalmother.org
}

How to cite this paper: Cappelli, M. L. (2021). Ayotzinapa 43: The Political Aesthetics of Drone Protest Graffiti. Advances in Anthropology, 11, 128-152. https://doi.org/10.4236/aa.2021.112009

Received: January 30, 2021

Accepted: April 6, 2021

Published: April 9, 2021

Copyright ( 2021 by author(s) and Scientific Research Publishing Inc. This work is licensed under the Creative Commons Attribution International License (CC BY 4.0).

http://creativecommons.org/licenses/by/4.0/

\section{(c) (i) Open Access}

\begin{abstract}
Mexico has a unique history of deploying man-hunting drones in its militarized arsenal of security patrols to control narco traffickers, bandas criminales and dissident populations. Considered to be the drone capital of Latin America with one of the first Drone Academies to teach the myriad aspects of drone piloting, Mexico is at the forefront of drone surveillance technology. It is also at the vanguard of Drone Art Performance. Angered by what is perceived as militarized surveillance warfare and a violent culture of corruption that operates with impunity, Mexican phygital graffiti artists and activists have responded in collective protest to these post-panopticon tactics with its own counter-hegemonic warfare-Droncita, Mexico's first grafitera drone. Droncita is an emerging art form that combines the ethical and subversive aesthetics of graffiti street art to physical spaces high above the ground to offer new models of spectatorship, testimony, participation, and political agency. First deployed after the disappearance of 43 students from Ayotzinapa teacher training college, Droncita represents a discursive space to revision art and humanity. This qualitative research demonstrates how surveillance technologies have been refocused and redeployed as an aesthetic genre of political activism and performance to challenge dominant discourses on militarized power.
\end{abstract}

\section{Keywords}

Ayotzinapa 43, Drones, Narco Traffickers, Drug Cartels, Mexico, Enrique Peña Nieto, Impunity, Corruption, Graffiti, Protest, Surveillance Technology, Paramilitaries, Lopez Albrador

\section{Introduction to the Disappearance}

On September 26, 2014, a group of 100 students from La Escuela Normal Rural Raul Isidro Burgos, in Ayotzinapa, Mexico headed off on their annual trip to 
Mexico City to commemorate the Tlatelolco Massacre in which state forces led by Mexico's military shot and killed hundreds of innocent students, protestors, and civilians on October 2, 1968. The Ayotzinapa students commandeered several busses, as was their typical way of transportation to the event. Around 9 p.m. on their way to Iguala to secure more buses for their caravan, local Iguala police officers blocked the roads, intercepted the buses and began haphazardly shooting at the students.

When we passed the town square, the first patrol cars arrived and began to use their weapons. They intercepted the third bus, which I was a passenger of and immediately began firing. We began to defend ourselves with rocks, which is all we could find and we yelled out, asking why they were shooting if we were unarmed", said Ernesto Guerrero one of the survivors of the attack.

With the police cars in front and patrol cars behind us, they started to shoot us. My friend got shot in the head and hit the ground. He is now brain dead (Vice, 2014).

Guerrero's story is substantiated by video footage of the event taken by an Ayotzinapa student with a cellphone. In the video, we witness the chaos and bloodshed.

We are unarmed! We don't have weapons! We don't have weapons, sir! Why are you aiming at us, we are unarmed.

I'm filming you, asshole. Keep aiming. Show everyone how you take aim at students. Too bad you don't do the same with Narcos!

Hey you killed my friend. You have already killed one of us. Hey! Officer! Our friend needs an ambulance. Get an ambulance. He is dying! He is dying! Bring the ambulance (Vice, 2014).

According to Guerrero's testimony of the event, students were abducted from the third bus, and their faces covered with hoods and thrown onto the curb. The Iguala police then chose 43 students who were loaded into police vehicles and carted away. 43 students were disappeared. Uncovering the historical truth of this event is complicated. Because of the coordinated involvement of state and non-state actors involved in the disappearance, it is difficult to untangle the web of culpability. Felipe de la Cruz, a graduate of the school and a parent of one of the surviving students, argues that "the state and the municipal government represent the face of crime and cruelty" (Vice, 2014). Mexican citizens have always understood the collusion between the cartels and the government, which is why they have had a hard time swallowing Attorney General of Mexico City Jesus Murillo Karam's November 7, 2014 press announcement on the alleged whereabouts of the 43 disappeared and the connection to the Guerreros Unidos drug cartel. According to Murillo Karam's report, the Iguala police handed over approximately 43 to 44 students to the members of the cartel who took them in a truck 15 miles southwest of Iguala to a garbage dump in a hidden ravine in Co- 
cula. According to cellular reportage at an airport hangar with the Attorney General and parents of the disappeared, the students were covered with layers of rocks, rubber tires, and firewood. "Like on a griddle", one of the accused testified. The "griddle" was then soaked with diesel and gasoline and burned for fifteen hours from midnight until 2 p.m. the next day on September 27 (Vice, 2014). The bodily remains were collected and put into black plastic bags and tossed into the river near the San Juan Bridge. Parents, human rights activists, and artists, however, continue to refuse this rendition of the historical event and want conclusive proof. The University of Innsbruck in Austria has identified only the corpse remains from two of the Ayotzinapa students. Several protests ensued targeting sitting president Enrique Peña Nieto and his administration's collusion with drug cartels, and failure to find the missing 43. "Renuncia Peña Nieto", "Fuera Peña", "Fuel el Estato", "Mas de 28 Desaparecidos" (Figures 1-4) became some of the narrative frames that phygital graffiti Droncita artists employed to take up cargo (charge) and bear aesthetic witness and aesthetic post-witness to the disappearance of the 43 .

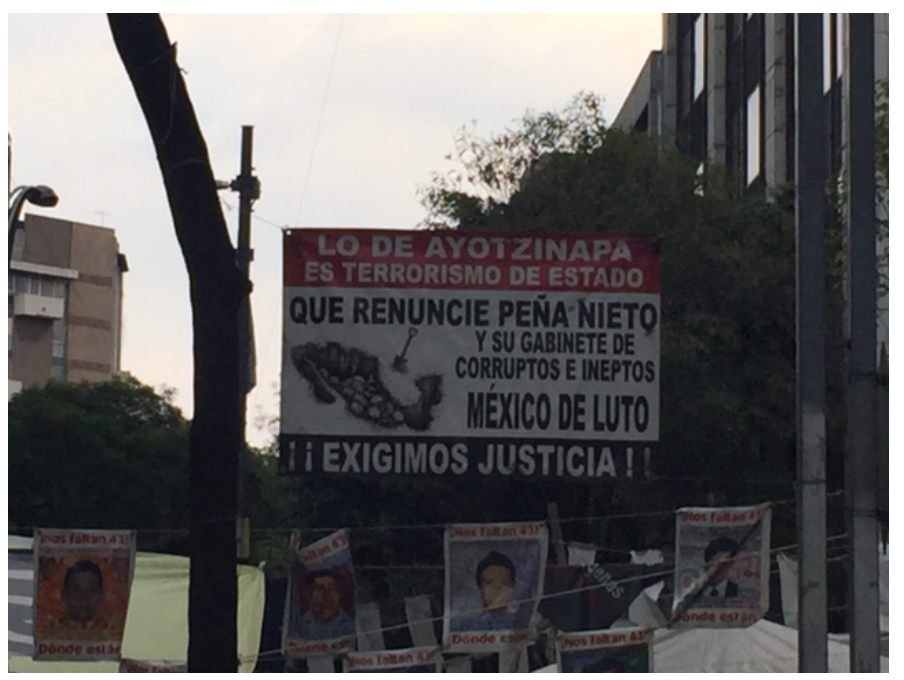

Figure 1. Renunciate Peña Nieto.

In this research, I examine how the Rexiste Collective of droncita artists and activists interrogates Mexico's violent culture of corruption and how Rexiste calls into collective memory the events leading to the disappearance of the Ayotzinapa students. I call on my interdisciplinary background as a theater artist, legal scholar, and ethnographer to analyze the droncita installments as theatrical performances that function as both symbolic and narrative representations. The refashioning of graffiti art to phygital graffiti with the utilization of drones heightens the artistic tension as it narrates history. Moreover, this form of phygital performance activism provides an ideological space of humanitarian intervention. Droncita performance revives the 43 students back into memory and inscribes their lives onto the Mexican landscape so that their stories are never forgotten. They function as harbingers of collective memory (Danchev, 2015: p. 
194). The political aesthetics constructs socio-political discourse to challenge, testify, and make visible the people and ideas that have been invisible or disappeared (Morrison, 2016; Roach, 1996; Silverman, 1996; Taylor, 1997, 2003). Droncita artists, in this sense, bear witness by fashioning "a moral community that will listen to their testimony" (Margalit, 2004: p. 155).

As vibrant multimedia installations, the performances offer the spectators a sensory call to also bear witness in the chronicling and reporting of history. In a sense, Rexiste Droncita (Figure 2) charges the state of Mexico for the disappearance of the students and inculcates onlookers, viewers, and spectators with cargo (charge) to watch, see, and listen. And, like most political performances, the wounds-social, political, and emotional-are opened and become the bridge towards transformation and healing (Strauss, 2013).

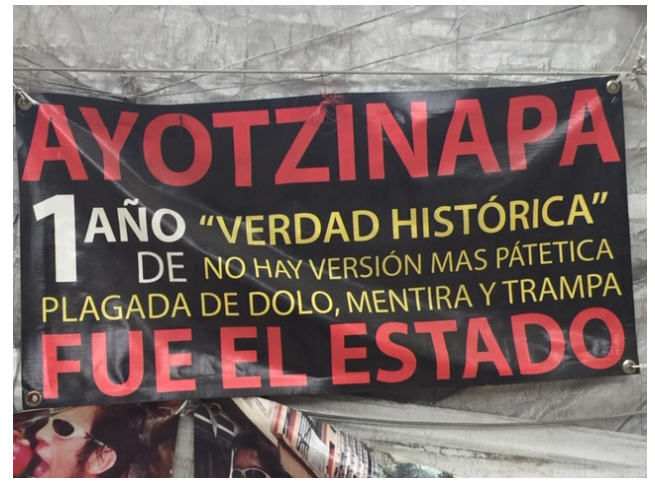

Figure 2. It was the state. Sign in Mexico City.

\section{Methodology}

Informed by Victor Turner's (1987) anthropology of performance, my research synthesizes a qualitative ethnographic methodology of data collection. In Mexico, in September 2014, December 2015, April 2016, and January 2017, I photographed protestors, conducted interviews with protestors, social activists, and artists, and analyzed video footage relating to the disappearance of the Ayotinzpa 43. Photographs and videos were uploaded onto Atlas.ti and the data was later coded, sorted, and mapped (White et al., 2010). My driving inquiry was to explore how Rexiste Droncita performances are linked to "larger social contexts of patterns" of corruption and impunity in Mexico (Lindekilde, 2014: p. 204). Norman Fairclough's (1992) approach to discourse analysis enabled me to examine the drone performance art as powerful discursive media platforms that challenge and disrupt dominant government discourses (Bauman \& Briggs, 1990; Lindekilde, 2014; Snow \& Soule, 2010). In analyzing the data, I determined several meta-patterns to determine the political call to action and dominant rhetorical patterns (Turner, 1987: p. 103). Within the Droncita Performance Art, I distinguished several demonstrative groupings of urgent rhetorical frames, which were often repeated through different media venues and glocalities and then transmitted through social media: Ayotinzpa 43; Fue el Estado; Hackear al 
poder, Es Hora a Cambiarlo Todo; FALTAN; PEÑA NIETO RESIGN NOW; No Mas Impunidad (de Certeau, 1984; Ginsburg, 1993, 2002; Hebdige, 1979). Taken as a whole, the performances proffered the "moral vision" to act in solidarity and "cambiar todo". Prior to examining the political aesthetics of Droncita Art Performance, it is first necessary to understand the history of drone usage in Mexico and its complicated relationship between government, drugs, death, and disappearance.

\subsection{Literature Review of Drone Presence in Mexico}

Sociologist Marx (1985) first introduced the idea of a surveillance society to explain the increasing infiltration of state and military surveillance technologies throughout the global world (p. 22). In Mexico, drones were first introduced into the arsenal against narco-trafficking with the 2011 surveillance agreement between US President Obama and Mexico's x-President Felipe Calderón. The agreement provided for intelligence gathering, with US Homeland Security and military operatives deploying both manned aircraft and drones along the 2000-mile US/Mexican Southwest border. As drug activities and homicides increased with 120,000 homicides registered during Calderón's term, so did the arsenal of surveillance, which began reaching deeper into the Pacific states of Michoacán and Guerrero, and Tamaulipas; surveillance continued to spread into Chihuahua and Baja California where the border cities of Juárez and Tijuana are situated.

Historically, US policy began in 1971 with Nixon's campaign on the War on Drugs. Nixon declared drugs to be "public enemy number one" (Dufton, 2012). The rise of narcotic activities along the Mexican border markedly intensified in the 1980s when US Customs Service and Department of Defense stepped up its air security along the coast of South Florida, which rerouted drug trafficking activity to transnational criminal organizations on the ground in Mexico (Andreas, 2017). Borrowing Nixon's sentiment on drugs, George H.W. Bush, in his first national televised address to the American public in 1989, declared drugs to be "the greatest domestic threat facing our nation today" (C-SPAN, 1989).

By the 1990s, the US Government declared the US Mexican border a "High Intensity Drug Trafficking Area", and launched an interdiction policy that engaged military support to stop the flow of illicit contraband into the United States. Bush's 19901033 Program was part of the National Defense Authorization Act that authorized the Pentagon to allocate military equipment to local enforcement agencies for use in "counter-drug activities". The 1990s also brought with it former President Clinton's signing of the North American Free Trade Agreement (NAFTA) also known by many indigenous peoples of Mexico as "a death sentence for the Indigenous People of Mexico", because the deal negatively impacted middle, low class and indigenous farmers who got caught in the crossfire of narco-traffickers and transnational agribusinesses.

Non-state actors in the form of vigilante groups began testing homemade re- 
connaissance drones between 2003 and 2004 in order to monitor the border for illegal immigrants. The American Border Patrol leader, Glenn Spencer, acknowledged that he began testing unmanned vehicles on July of 2003 as a means to track illegal border crossing activities (Moscoso, 2003). Shortly after American Border Patrol began testing and using drones to patrol the border, the CBP began its own testing with an Israeli-made, Elbit Hermes 450, to fly test runs between June and September 2004. In October 2005, the CBP launched its drone predator along the southern border. In 2006, it crashed into the Nogales hillside in Arizona after its engine was shut down midflight precipitating one of the first investigations into an unmanned aircraft (Michel, 2015). With the cooperation of the Mexican Government, the Obama Administration launched Global Hawk drones to gather intelligence on drug trafficking organization (DTO) locations. Mexican DTOs are polydrug organizations that engage in the sale and export of many types of drugs including heroin, fentanyl, marijuana, cocaine, methamphetamine and other types. Of the heroine seized in 2015 in the United States, Mexico produced 93 percent of it (Beittel, 2018). Because DTOs have expanded their activities to include other criminal activities including kidnapping, human smuggling, and extortion, to name a few, they are also referred to as transnational criminal organizations (TCOs). Transnational criminal organization (TCO) activity along the Northern Mexico's US/Mexico border and its surrounding cities and interior regions has increased dramatically year by year (Mazzetti, 2012).

While homicide rates decreased proportionately during the early years of Peña Nieto's six-year term, the homicide rates began to rise incrementally with $7 \%$ in 2015, 22\% in 2016, and 23\% in 2017 (Beittel, 2018). In 2017, Mexico reached its highest number of total intentional homicides in a year, exceeding, by some counts, 29,000 murders. According to a security consultancy that tracks these types of homicides, in the 2017-2018 election period that opened in September 2017 and ran through June 12, 2018, 114 candidates and politicians were killed allegedly by crime bosses and others in an effort to intimidate public officials (Beittel, 2018). In fact, 150,000 intentional homicides since 2006 are connected to organized crime.

Up until this point, there was little recorded data on TCO activity as states failed to see these non-state actors as major players in maintaining the security of their citizens (Manwaring, 2012). Transnational criminal organizations, bandas criminales are politicized entities carrying a dangerous far-reaching agenda to secure the success of their commercial interests. In order to ensure their profit margins, they must control individuals, communities, territories, resources and transportation routes. It is an understatement to say that these activities disrupt lives and threaten the stability of the region (Manwaring, 2012).

The US rhetoric on TCOs changed with the 2016 election of President Donald Trump. Trump called for the construction of a physical wall to stop the "bad people", who he also referred to as "animals" (Davis, 2018). In spite of closing down the government for three weeks, President Donald Trump (2019) argued 
for a physical wall as "you can't have Border Security without a Wall. The Drones \& Technology are just bells and whistles" (Rampell, 2019). Yet, Trump's Principles, Standards and Procedures on drone operations have exceeded that of the President Obama May 2013 Presidential Policy Guidance (PPG), which established the "near certainty" and "continuing and imminent" standards for drone strikes and the preference for capture operations. Under Trump Administration's PSP policy wider permissibility and latitude is granted to conduct drone strikes and covert operations outside of conventional battlefields. In 2017, US Customs and Border Security completed 635 missions along the US/Mexico border breaking all previous records and recording over 5,625 hours of flight time. The surveillance drones have advanced security and surveillance of narco activities and illegal migrant and dissident populations.

To date, there are several TCOs vying for control of communities, lands and resources in Mexico. In addition, to the top well-known cartels, Juarez, Gulf, Sinaloa, and Tijuana, there are several others. The Jalisco New Generation, which got its start around 2010 now challenges the Sinaloa Cartel for power and command of Tijuana and the port of Manzanillo and other strategic areas. The Jalisco Cartel is responsible for a series of attacks on security forces and public officials. In addition, the Beltran-Leyva, Los Ántrax, Gulf, Familia Michoacána, and the Zetas cartels are also key players. The crackdown on cartels throughout the region has only caused more fragmentation, leaving cartels vying for control over regional infrastructures, and in some instances forcing them to diversify their enterprises into other criminal activities (Nugent, 2018). In May of 2018, a civilian was killed every fifteen minutes. Current President Andrés Manuel López Obrador (AMLO) describes his country as a "war zone" and acknowledges the overlapping network of "corruption within the civilian federal, state and municipal police forces" (Martinez, 2018). Indeed, it is important to note that in most cases, nongovernmental actors are assisted by government, military, and paramilitary assistance. The widespread corruption and impunity intensify the violence, an important connection that Droncita Artists point out in their performances. It is, moreover, important to note that with the crackdown on drug smuggling, cartels have found innovative ways to challenge physical security, walls, and barriers. In reality, it appears that the US/Mexico militarized defensive strategies to curtail the spread of TCO activities are "shaped by the very defenses put in place to stop it" (Kimball, 2016). The innovative deployment of Narco drones is a response to militarized curtailment.

\subsection{Drones, Drugs, Death and Disappearance}

Mexican drug cartels are the first cartels in Latin America to deploy Narco drones, unmanned aerial vehicles, UAVs (Fiegel, 2017). Narco drones first appeared on the US Mexico border in 2010. In 2013, the Drug Enforcement Agency (DEA) estimated approximately 150 narco-drones had transported approximately two tons of cocaine and other drugs across the border (Giraldo, 2014). According to Francisco González, Undersecretary of SSP at the time, the cartels' 
new technology has made drug transportation efficient and economical capable of flying below DEA's radar (Neal, 2014). The early drones weighed roughly one hundred pounds and were capable of carrying a hundred kilograms of drugs garnishing traffickers $\$ 2$ million dollars per flight. Reportedly, the drones are made at aircraft factories such as the one in the Santa Fe District of Mexico City by aircraft engineers working for the cartel on their off hours (Neal, 2014). With all of the drone usage in Mexico, it is not surprising that it is also one of the first countries to open up a Drone Academy in 2015 in order to teach the successful piloting of drones for myriad of purposes, including rake-off, landing, displacements, and surveillance. Drone Academy Director, Jose Luis Gonzalez, said he opened the school because people were purchasing the drones without knowing how to use them (Fernando de Castro, 2015). As of March 2019, cartels have been using drone aircrafts to not only smuggle drugs, but also for surveillance purposes, and for attacking and killing opposing forces, which attempt to interfere with their criminal activities (Sanchez, 2015). Drones present a challenge to US Border Security and Customs because they flow below the radar. According to Mike Vigil, former Chief of International Operations at the US Drug Enforcement Administration (DEA), "armed drones may be the 'way of the future' for Mexican cartels engaging in cartel warfare” (Omedo, 2018). Shaw and Akhtar's (2012) admonition is correct in that drones have become algorithmic technologies of death and destruction and are multiplying across the global horizon.

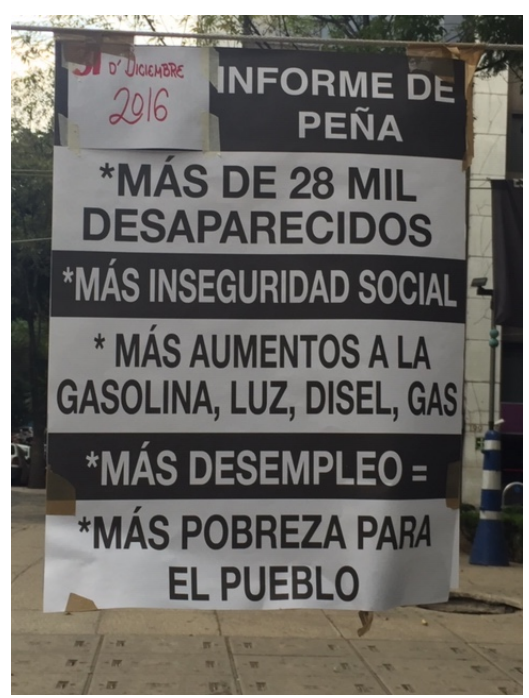

Figure 3. More than 28,000 disappeared.

In July of 2018, two-armed drones targeted Public Safety Secretary Gerardo Sosa Olachea in his home in Tecate, Mexico. One drone was used for surveillance of Olachea, the other was equipped with two IEDs improvised explosive devices, which failed to explode. It is believed the attack is a response by the three major cartels operating in the area: Tijuana Cartel, Sinaloa Cartel and (Cartel Jalisco Nueva Generación (CJNG).

Weaponized drones that wed Techniques, Tactics, and Procedures and IEDs, 
developed by the Revolutionary Forces of Colombia are now used throughout Mexico (Kryt, 2017). While China's Dajaing Innovation continues to dominate the 70 percent of small drone commercial market, the US and Israel are the biggest manufacturers of military grade drones (Wang, 2016). Israel, in particular has a long history of aiding the Mexican government in squashing political dissent. Since the 1970s Israel has sold "field tested" Israel Defense Force weapons. In 2009, UAV maker Aeronautics Defense Systems Ltd. contracted to sell advanced surveillance and intelligence systems valued at $\$ 22.5$ million to Mexico's federal police force (Tsipori, 2009). The surveillance system allows for the identification of people 4.9 miles away and "pinpoint(s) their location on digital maps" (Tsipori, 2009). In 2017, Israeli Prime Minister Benjamin Netanyahu along with several businessmen visited sitting president Peña Nieto to establish free trade agreements. To date, several Israeli firms have contracted to sell drones to "protect for 'sensitive installations' and to patrol Mexico's southern border" (Webb, 2017). Israeli cyber-tech surveillance drones have been linked to the monitoring of domestic dissidents, human rights advocates, anti-corruption advocates, and media journalists (Amnesty International, 2019). Because Israeli companies only contract for the sale of its products to Mexico, surveillance and other usage "are believed to have been state-sponsored" (Webb, 2017).

The U.S. Department of Defense (DOD) sent unmanned aerial vehicles along with training equipment and technical support to gather intelligence information on DTOs and CTOs along the U.S. border regions. The Mérida Initiative, a bilateral anticrime package introduced in 2008 under President Calderón's administration concentrated on supplying military grade unmanned vehicles, "equipment, technology, and training to stop the flow of weapons, money and the demand for drugs" (The Merida Initiative, 2008). It is evident that the militarization of the drug war is big business. Under Peña Nieto's presidency, Mexico surveillance technology was deployed as a military strategy for domestic policing of civilian populations in addition to the policing of DTOs and CTOs. In 2014, Peña Nieto instituted another military component in the creation of a gendarmerie, a national, militarized police comprised of both military personnel and police, which operates under civil law enforcement jurisdiction. In 2014, the Federal Police's Gendarmerie Division, deployed 5000 police agents to provide additional government surveillance of its civilian legal and illegal activities. The result was also an increase in human rights abuse charges against the Mexican military (Seelke \& Finklea, 2017).

Human Rights abuse in Mexico is not new. According to Human Rights Watch approximately 34,000 people have been disappeared since President Felipe Calderón launched his "war on drugs" (Broner, 2018). One of the most horrendous uses of military force happened in San Pedro Limón with the Massacre of Tlatlaya on June 30, 2014 when the 102nd Battalion massacred 22 young people. The National Human Rights Commission found 855 unmarked secret graves of 1548 bodies between 2007 and 2016. In addition, security forces killed 4000 civilians "between Dec. 1, 2006 and Dec. 31, 2014; 3967 civilians and 209 
soldiers have been killed between 2007 and 2014" (Carlsen, 2015). In September 6,2018 , in the state of Veracruz, Mexican investigators used drones and radar to uncover one of the largest mass graves of 166 human skulls and 200 personal clothing items. According to State prosecutor Jorge Winckler, "The state has become a cemetery" and he is deploying drones throughout the region to find more bodies (O'Grady, 2018). Winckler argues that drug gangs, working in collaboration with government officials, arrest members from rival cartels, torture, kill, and disappear their bodies.

Forced disappearances have caught the attention of the international community as well as the artistic community. On September 26, 2014, a few short months after the Massacre of Tlatlaya, 43 male students were disappeared from the Ayotzinapa's Raúl Isidro Burgos Rural Teachers College in Iguala, Guerrero, Mexico. Only one of the bodies has been discovered. The 43 students were undertaking their annual trip to Mexico City to commemorate the 1968 Tlatlaya Massacre when they disappeared. Their disappearance inspired the Rexiste Collective to artistically challenge the Mexican Government, and specifically Peña Nieto through myriad Droncita installations that were then spread across imagined digital communities.

\section{Rexiste Droncitas}

As mentioned previously, the 43 disappeared males have become a symbol of the culture of Narco violence, corruption and impunity in a country where, according to the UN, more than 150,000 people were killed between December 2006 and August of 2018. Since 2016, an estimated 30,000 people have been forcibly disappeared, 855 mass gravesites have been discovered, and an additional. By 2020 , the estimate rose to 73,000 people who have disappeared with no trace. In order to challenge the destructive power of drug drones, weaponized drones, and surveillance drones, phygital graffiti artists and activists subvert its usage as a strategy to enter into political discussions with an innovative counter-discourse of their own. As Nietzsche (1968) observes art provides an escape and "a certain freedom from moral narrowness and corner-perspectives", and in many instances "mockery" of the impositions placed on freedom of expression (p. 823). Mexican artists fight back with their own corner-perspective, not with guns and/or conventional materials, but with La Droncita, the first grafitera drone in Mexico. Many activists regard drones as the worst human advancement since the nuclear bomb. The grafitera artists heed the destructive nature of drones by subverting them to pay moral witness to their own destructive nature. The droncita presents the collaborative crossing of Mexican poster technology and TTP (tactic, technique, and procedure) to provide a discursive space to revision art and humanity. Droncita opens up innovative ways to artistically communicate fresh ideas and ways of being and existing in a conflicted world (Rancière, 2004, p. 13). It represents another "social turn" in art, which offers an intersectional link to guerilla graffiti art that is produced in public places (Bishop, 2006). Rexiste, whose name is a derivation of the words to resist and exist, emerged from 
the student movement \# YoSoyl32 that arose to oppose the candidacy of Peña Nieto and denounce the giant broadcast Televisa for its biased coverage. Responding to the age of surveillance technology, Compañeros de Droncita reproduced its "hegemonic power and reacts to its political environment", through its performances (Duncombe, 2016: p. 433). In one of its major activist art performances, Rexiste equips its drones with spray cans and obliterates a portrait of Peña Nieto throughout Mexico City. Rexiste operates within an aesthetic politics of spectacle and disruption enabling individuals to collectively participate in a public discursive display (Rancière, 2004: p. 12).

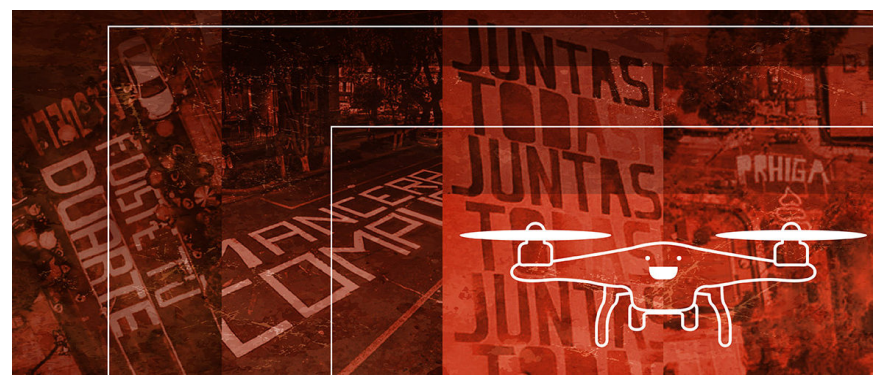

Figure 4. Droncita figure drawing.

Although Rexiste operates with droncitas, they assert that they are not artists or activists. Instead, they claim to deploy the drones as a strategy to "enter the public space, engage in public debate and hack the political discourse". In so doing, Rexiste establishes a rhetorical venue of ethical responsibility between the subject, the object, and the observer/witness. The droncitas are their weapons in the fight against authoritarianism and "a military dictatorship that grows in the midst of international silence". Performance Activism in public spaces has always been contentious for existing political structures as it specifically targets these structural forces as a productive strategy to publicly destabilize their power (Morrison, 2016). Rebellion and change must first "be rehearsed" before it is performed and built out in the world of movements, organizations, governments, and power in the future (Duncombe, 2016). Until the bloodying of Peña Nieto with its droncita, the group was best known for its performative activism (Figure 5) delivering a very public verdict in the Ayotzinapa Disappearance by defacing Mexico City's Zócalo Square with 30 liters of paint and three large words: "Fue el Estado. (It was the state)". In the remaining sections, I analyze the three Droncita Performance Installations, informed by Walter Benjamin's understanding of "aesthetics" as a type of knowledge centered on the "sensory experience of perception" (Buck-Morss, 1992: p. 6).

\section{1. (Fuel el Estado) It Was the State}

Droncita Rexiste's first collaborative improvisatory performance takes place in Zocalo Square as seen in Figure 5. In this theatrical performance, entitled Hack the Power, we witness how art directly engages with social and political concerns. Since the Zocalo is a visible architectural place of social interaction and 
political power, the artists have physically taken over the time and space as a means to disturb the public sphere, disrupt the dominant discourse and shame the government (Critical Art Ensemble (CAE), 1996; Groys, 2014; Mouffe, 2007; Tufekci, 2017). The Rexiste drone videographer records the event and locality in real time, as it is physically inhabited. The content and "locality" is then sent across the Internet to form "glocalities" of "interconnections" that transmit the experience of the local (Meyrowitz, 2005). Hack the Power constructs virtual "glocalities" that are "primarily relational and contextual, rather than as scalar or spatial", as they constitute "a series of links between the sense of social immediacy, the technologies of interactivity and the relativity of contexts" (Appadurai, 1996: p. 178). The glocality emerges as a space of shared consciousness in which members engage in a network of "texts, images, interpretative frameworks and horizons of experience" (St. Amant, Sapienza, \& Sides, 2017: p. 19).

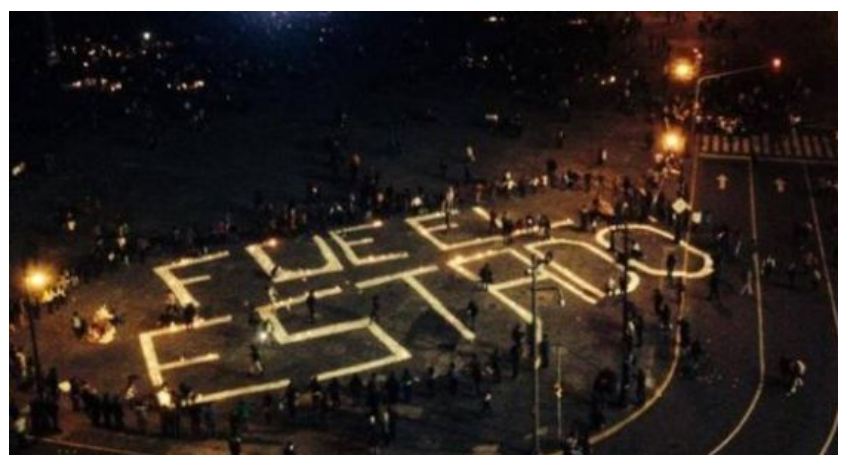

Figure 5. Fue El Estado. It was the state.

In the video of the protest art, we first see a hand with a roller speed painting white paint across Zocalo Square. The anonymous roller painting is accompanied by the cacophonous sound of metal cans and bells, which creates a jarring sense of alienation. The rolling paint fuels the repetitive motions and suggests the mechanized repetition of "wordless experiences" (Elkins, 1999: p. 193) We then hear a distorted, robotic female voice over, accusing the government and its security forces of involvement in the disappearance of the students. In a mechanized voice she says:

"Hace un ano, trente litros de pintura y cientos de miles de personas pusierion en la mira a los culpables."

A year ago thirty liters of paint and hundreds of thousands of people put those responsible in the spotlight (Rexiste, 2014).

A young woman with long brown hair, yet still unknown, is shown as the artist. The metal tin drumming and bells intensifies as a drone hovers over the square. More painters roll large white paint in block letters. The painters collectively encircle their declaration: "Fue el Estado" to the voice over: "Asi de sencillo es hackear al poder." (How easy it is to hack the power; Rexiste, 2014: p. 19, 27). The drone camera trembles and the sound intensifies to a frenzied shaking 
as it pulls back on the square. "Hoy, no hay vuelta atras." (Today, there is no way back; Rexiste, 2014: p. 22, 27). In bold white letters superimposed on a blurry scene the female narrator reads the title card:

Es Hora a Cambiarlo Todo. (It's time to Change Everything; Rexiste, 2014: p. 24, 27).

The performance that emerges is the people's history of the events and collective memories of the events. The manifesto, "Fue el Estado", calls on the people to take back the power and change history. The artful protest is both a social protest and a call to action to right a wrong. The artistic representation of the anonymous hands of unseen painters and artists, in addition to the drone recording of the space, movement, and bodies show the complex complicity of governmental and non-governmental actors involved in the disappearances. The artists' anonymity calls into question, not only the identity of the artists/activists but also the social concerns about identity and social ownership itself (Bishop, 2006; Lind, 2007). Are the artists anonymous because they fear military repercussions for challenging the state? Are they anonymous because the identification of the perpetrators of the 43 Ayotzinapa murders has remained anonymous? One certainty is that the artists are the secret agents of collective memory, provoking its viewers to remember the truth. The drone video surveillance metaphorically heightens the artistic anonymity and interrogates the complicated disciplinary measures of the seen and unseen within a political performance. The result is an artful multi-sensory protest spectacle that in a Gramscian (1971) sense challenges history and articulates new ideas and truths about the recording of historical events and happenings (Duncombe, 2016: p. 439). The challenging counter-hegemonic manifesto advances an alternative historical truth of the event, which reinforces the idea that history, truth, knowledge-are social constructs that serve to validate and sustain existing political and social structures (Heywood, 1994: p. 101). Arjun Appadurai regards locality as "primarily relational and contextual, rather than as scalar or spatial", that is, "as a complex phenomenological quality constituted by a series of links between the sense of social immediacy, the technologies of interactivity and the relativity of contexts". We no longer live in localities (Meyrowitz, 2005: p. 23). As a result of the new communication and transport technologies, we now inhabit glocalities, in which a global matrix of interconnections has overlaid our experience of the local. Although for Meyrowitz each glocality has unique features, all glocalities are now shaped "by global trends and global consciousness" (2005, p. 23). Rexiste brings into consciousness the 43 Ayotzinapa students to a virtual community so that memories can be collectively shared, lived, and experienced across networks and geographies (Postil, 2011: p. 12).

\subsection{Es La Hora a Cambiarlo Todo}

El primer drone grafitera en México exige la renuncia del "president." Le premier drone de graffiti au Mexique exige la renonce du président. El primer Drone Graffitero de México nace en el límite de lo admisible: 
Ayotzinapa. Quisieron engañarnos pero no lo lograron. Es momento de cambiarlo todo. En este punto de quiebre la única solución es DESENCUARTELAR LA VERDAD para obtener justicia. Ayotzinapa es el inicio de una historia, nuestra historia. Quienes dicen estar de nuestro lado mientras nos asesinan tienen que largarse. Cumplir las exigencias de las familias es lo mínimo. No aceptaremos un no por respuesta.

The graffiti drone in Mexico that demands the resignation of the "president" The first Grafitera drone of Mexico is born in the limit of the admissible: Ayotzinapa. They wanted to deceive us but they did not succeed. It's time to change everything. At this breaking point, the only solution is to discover the truth in order to obtain justice. Ayotzinapa is the beginning of a story, our history. Those who say they are on our side while they kill us have to leave. Meeting the demands of families is the minimum. We will not accept a "no" for an answer (Rexiste, 2015a).

I examine "Es hora de cambiarlo todo" as a political drone phantasmorgia-a sequential explosion of horrific images and sensory assaults (Buck-Morss, 1992: p. 6). Here, graffiti street art and grafitera drone art take over the historical moment and the daunting questions of the dangerous elements of surveillance technology in the hands of corrupt governmental and non-governmental actors. This grafitera phantasmagoria facilitates a critical participation in the generation of meanings, and representation of truth (Cohen, 1999: p. 256).

The film of the drone performance itself opens up with a camera low angle shot of trash and rubble of an abandoned building. Eerie garage band music plays in the background as the camera then slowly spans up the face of the building. A distorted female voice says: "ESTO NO ES EL PAIS QUE SONASTE". This is not the country you dreamed about (Rexiste, 2015a: p. 3, 39). The camera looks up at the subject-the figure of a man painted in white with his hands spread out as if he is Jesus welcoming his followers (Figure 6). The low angle suggests that the shrouded figure is in a position of power. The camera then shoots straight ahead and transmutes into the picture of $57^{\text {th }}$ President Enrique Peña Nieto. The images along with the frenzied electronic music flood the senses. The electronic female voice says, "Pero es lo ya tu sabes" (Rexiste, 2015a: p. 6, 39; You already knew this). Her declaration implicates the viewer in the responsibility of Mexico's history. A close up of the word FALTAN (MISSING) is spelled out letter by letter on the side of the wall. Immediately, fast speed consecutive red numbers appear beginning with $1,2,3,4 \ldots$ first starting at the top of Peña Nieto's forehead then pulling back over his face and upper body. The electronic voice says: “AYOTZINAPA FUE EL PRINCIPIO..." (Rexiste, 2015a: p. 10, 39; Ayotzinapa was only the beginning...) The numbers then freeze on 43 indicating the 43 missing students. The public's political conscious is startled and awakened by the image of Peña Nieto and the historical number: 43 (Cohen, 1999: p. 256). The frame blurs and a white drone materializes in focus. The voice continues. \{D\}E NUESTRA HISTORIA" (Rexiste, 2015a: p. 13, 39; Of our story). 
The camera then cuts to Peña Nieto accompanied by the voice "DE SU FIN" (Rexiste, 2015a: p. 15, 39; Of his end). Employing an aerial shot the camera pans down to the white grafitera flying towards the abandoned building. "TRATASTE DE ENCUARTELAR LA VERDAD”. You tried to lock the truth (Rexiste, 2015a: p. 18, 39). A High angle points down towards Peña Nieto, the word FALTAN in red block letters over his head. "TRATASTE DE ENGAÑARNOS." You tried to fool us (Rexiste, 2015a: p. 20, 39). In a theatrical dialectical manner, perception is manipulated to assign blame to the president, the transmission of which becomes an alternative construction of Mexico's history of the disappeared and disappearing. According to Terry Castle (1995), the phantasmagoria "carries with it powerful atavistic associations" of the "supernatural" and the uncanny, which unsettles its witnesses (pp. 141-144).

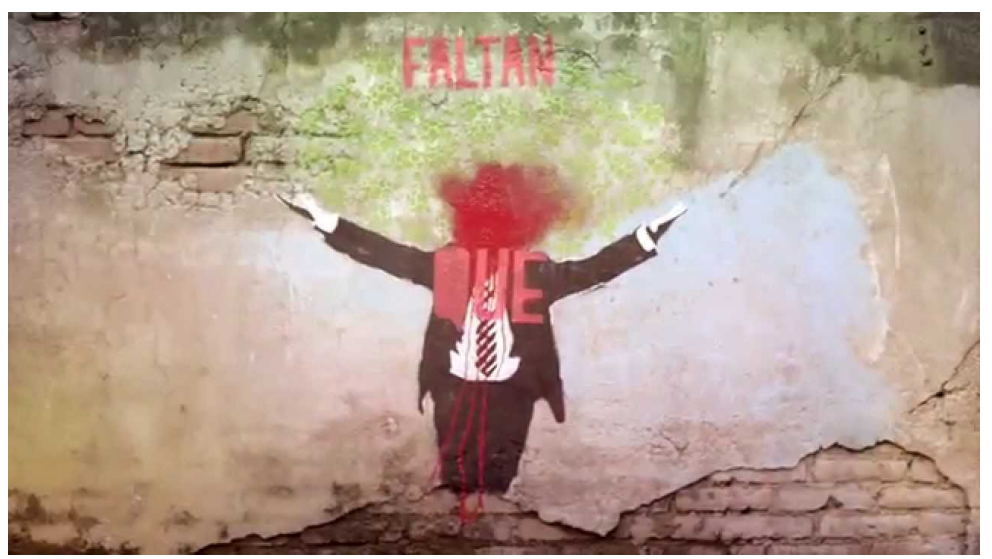

Figure 6. Bloodied image of Nieto.

The grafitera descends and takes aim at Nieto. "ES TIEMPO A CAMBIAR TODO" (Rexiste, 2015a: p. 22, 39; It's time to change everything). Musical orchestration intensifies the political energy with a tin like shooting and an overiding heavy base sound. A grafitera strapped with a spray can of red paint zooms in on Nieto's head. The grafitera obliterates and bloodies his head completely subsuming it in blood-red liquid. The spilt blood represents the blood on Nieto's hands as well as the blood of the missing and disappeared. The camera pulls back to reveal Neito's bloody head, a short fleeting second and the block letters: FALTAN and QUE SE VAYA over Nieto's body. They are missing (Rexiste, 2015a: p. 22, 39). The final title card reads in English:

\section{PEÑA NIETO RESIGN NOW}

The video ends with \#DRONCITA in black block letters on the wall. Here, the blood is spilt and viewers are called on to inspect the unsettling dialectical movement from the time the blood is sprayed until the frozen moment when Nieto's face is fully covered. In this theatrical performance, the drone artists employ drastic dialectical images to convey the historical truth of the 43 disappeared. As Walter Benjamin (1999) points out: "Only dialectical images are genuine images", as they are charged with the historical truth (p. 462). The drone 
paint weaponry targets who is responsibility for the missing 43. "What has been is to be held fast-as an image flashing up in the now of its recognizability" (Benjamin, 1999: p. 473). It is Peña Nieto. Indeed, he is both looking and being looked at by the drone, the videographer, and the viewers, which codifies government surveillance practices and "mainstream visual media" practices (Morrison, 2016: p. 14). The grafitera artists create a virtual surveillance world where both panopticon and the synopticon exist. Initially, we see Peña Nieto as one of the few watching and hovering over his community. Then, in a different metaphor, the grafitera creates a sense of the many people, the marginalized, the vulnerable, the disenfranchised, the mothers and fathers of the disappeared-all watching the few. The past (disappeared) and the present (disappearing), the many and the few are relentlessly linked in a complicated political battleground of material struggles (Pensky, 2004: p. 180). It is within this liminal space of past, present, and future that the politics of disruption occurs. The drone performance discourse disrupts linear historicity of "political truth" and works as an antagonistic articulation that grants historical voice to the voiceless. The "slippery" representation destabilizes previous "truth claims of evidence, data, and information that prop up surveillance society" (Morrison, 2016: p. 12).

The testimony of the drone artist and the video-graphic artist records "an urgency to communicate a problem" by placing issues of oppression, poverty, and social injustice "on the agenda" (Beverly, 2004: p. 37). Here, the past and present are charged with taking responsibility in order to move into the future. In effect, the testimony of the Droncita is, in essence, linked to solidarity and "struggles around human rights" (Beverly, 2004: p. 77). The intentionality of the drone bears witness to a divergent position of history in which the droncita artists take up "cargo" (charge) to disclose historical truths and realities. In addition, the performance carries with it multiple symbolic meanings, which triggers Mexico's collective memory. Not only does the narrative suggest that Nieto has blood on his hands, but metonmyically testifies to the belief that the government and its actors have blood on their hands and are metaphorically culpable. Rexiste's command of symbols as a rhetorical strategy is persuasive (Williams, 2004). The drone personifies the all-knowing, all-powerful "eye of God", and his/her retributive vengeance for past crimes and transgressions against humanity (Chamayou, 2014: p. 39).

The resistance aesthetics is at the core of politics and a form of experience, which critically challenges the government's narrative and exposes the connection between power and powerlessness (Rancière, 2004: p. 13). The bloodying of Nieto's head is a revolutionary tactic indeed as it manifests a reality and acts it out for the world to witness, if the truth is ever to be uncovered (Duncombe, 2016: p. 451). The political representation calls for critical vigilance and epistemic change by calling on the powerful and the powerless to trulylook at history; to look is to engage in a dialectic of collective witnessing and inclusive meaningful dialogue. 


\subsection{The Hunger Games}

A las 18:19 hrs del 2 de octubre de 2015, diez minutos después de haber iniciado el mitin que encabezaron el Comité 68 y las familias de Ayotzinapa, el gobierno comenzó a transmitir un audio desde altavoces colocados en Palacio Nacional. A las 18:45 mientras la policía avanzaba un operativo desmedido, en las redes sociales, miles de bots replicaban el mensaje "Marcha 2 de octubre: Lanzan petardos y objetos contra Palacio Nacional; despliegan antimotines." Diez minutos después, a las 18:55, el Zócalo quedó vacío. El audio seguía sonando. ¿Qué ocultan? Un año después de la desaparición de los normalistas, en sólo quince días, dos manifestaciones multitudinarias han reclamado la responsabilidad del Ejército. No pueden desaparecer la verdad. El Ejército debe rendir cuentas. \#Desencuartelen LaVerdad.

At 18:19 hrs on October 2, 2015, ten minutes after the start of the meeting led by Committee 68 and the Ayotzinapa families, the government began broadcasting an audio from loudspeakers placed in the National Palace (Figure 7). At 18:45 while the police were advancing an excessive operation, in social networks, thousands of bots were replicating the message "March October 2: Firecrackers and objects are thrown at the National Palace, deploying anti-riot.” Ten minutes later, at 18:55, the Zócalo was empty. The audio kept sounding. What are they hiding? A year after the disappearance of the normalistas, in just fifteen days, two multitudinous demonstrations have claimed the responsibility of the Army. The truth cannot disappear. The Army must be accountable. \#Desencuartelen La Verdad (Rexiste, 2015b).

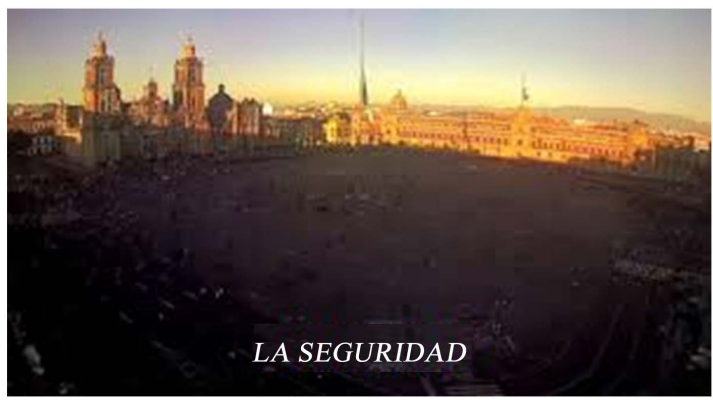

Figure 7. Image taken from Drone above the Zocolo.

A drone videographer hovers over the Zocalo, the main square in La Plaza de la Constitución in Mexico City where crowds of people and supporters of Ayotzinapa families assemble to witness the meeting between Committee 68 and the Ayotzinapa families. In the frame, we see we see the Presidential Palace, the Metropolitan Cathedral of the Assumption of the Most Blessed Virgin Mary, and the government offices. The editing appears as if the drone records at fast speed sequence. A male voice speaks in Spanish advising the viewers/witnesses as to what is about to unfold. The subtitles reads: "Esto Se escuchaba". The Message 
was heard (Rexiste, 2015b: p. 1, 35). "Desde los Altovoces" (02:35; From the loudspeakers). "De Palacio National" (04:35; From the National Palace). The man stops speaking and the point of view switches to a female voice of admonition to the people assembled in the Zocalo.

Entendemos y respetamos su derecho constitucional a de mantenarse su actuara de conformidad con la ley para mantener la seguridad y el orden de publico.

We undersand and respect your constitutional right to protest. The authority will act in accordance to the law.

To maintain security and public order (shots/firecrackers are heard)

(Rexiste, 2015b: pp. 4-15, 35).

The camera shakes with relentless fervor as shots are heard to disperse the crowd assembled in the Zocalo. Fast motion visuals show moving people, birds flying. Anchored off-center is an oddly slow waving Mexican flag. The fast-moving images constructs a demonstration of extraordinary power. The screen then turns black and the electronic female voice we heard in the previous videos reads block white lettered words written one at a time on the black screen.

ESTO

ES

$\mathrm{LO}$

QUE

LA

VIOLENCIA

ESTA

OCULTANDO (This is where the violence is hiding)

(Rexiste, 2015b: p. 17, 35).

The video then jump cuts to the streets surrounding the Zocalo where protestors march with banners shouting: "Uno, dos, tres, cuatro cinco, seis." The drone appears to speed through the crowds, capturing rows of protestors lined ten deep and an assortment of people at their side. As the drone moves through the street, we see many banners, creating an atmosphere of artful protest in which the multitudes are embraced in an politics of discursive engagement and manifestation. Protest translates to manifestacion in Spanish. In this case, it is the solidarity of the people in the manifestation of the truth. One banner reinforces this collective singularity. "HOMBRO CON HOMBRO. CODO CON CODO. LA FECSM, LA FECSM SOMOS TODOS" (Rexiste, 2015b: p. 19, 35; Shoulder to shoulder. Side by side. WE ARE ALL FECSM). The acronym FECSM stands for the Federation of Rural Peasants of Mexico, which according to their Facebook page is:

A student organization created in the year of 1934 and formed by 16 Rural Normal Schools, which are distributed throughout the country, its main objective has been since its founding, provide education to the children of peasants and defend the rights of the people, following the Leninist Marxist 
line.

The camera pans to the next banner as seen in Figure 8: "A Salvar Normalismo Rural" (Rexiste, 2015b: p. 20, 35; Save Rural Normalism). The crowd continues to shout, the numbers jumping to "trece, catorce, quince" (thirteen, fourteen, fifteen).

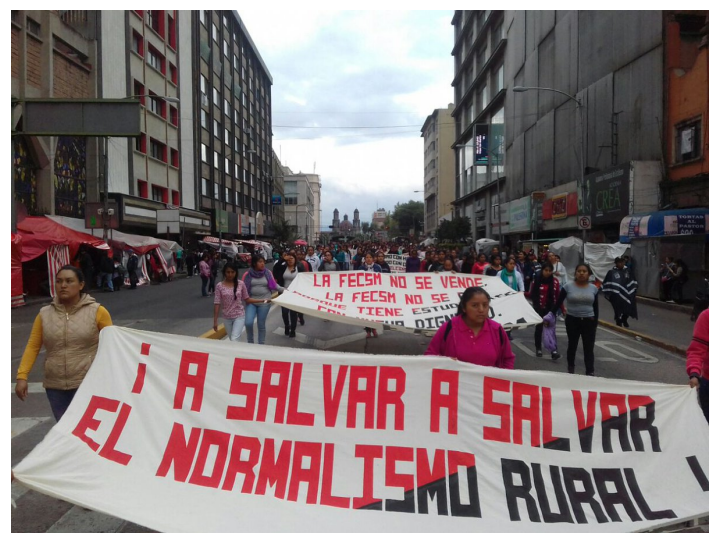

Figure 8. Save the rural normalism.

The camera then pans over the street closing in on the red carpet, the symbolic blood spilled at the hands of the government. Hundreds of protestors stand behind it revealing an emotive display of mutually shared concerns, solidarity, and community. Then another cut jumps to protestors emerging from a tunnel. They chant the numbers "veinte-dos, veinte tres, viente-cuatro", $(21,22,23,24)$ and hold a banner: "No Mas Impunidad" (Rexiste, 2015b: p. 26, 35; No more Impunity). This is followed by another abrupt cut to the remaining numbers. The crowd counts down: "Trenta y siete, trenta y ocho, trenta y nueve" (Rexiste, 2015b: pp. 27, 35, 37, 38, 39). The drone camera rises above the street as the final numbers are counted off: "(Cuarenta y uno, cuarenta y dos, cuarenta y tres" (Rexiste, 2015b: pp. 32, 35, 41, 42, 43). The drone offers a panoramic view zooming out and tilting down on the streets of Mexico, its varied buildings cluttered on the horizon. The sound crescendos and the screen goes black. The electronic female voice reads: "ES HORA A CAMBIARLO TODO", (It's time to change everything.) The single words appear one at a time in white block capital letters pushing the viewer forward to its conclusion (Rexiste, 2015b: p. 35).

The kinetic speed of the sequencing of protestors in real time while shots are fired suggests the uncanny omniscient power to manipulate reality. The loud sounds of gunfire send shockwaves through the Zocalo scattering the people. There is no need for translation here; gunfire transcends language and cultural barriers. The poly-vocal narration-the male introductory voice, the governmental voice, the female electronic voice, as well as the chanting crowds-drive the message forward and push the viewer to a collective desire to know the truth. The manipulative interplay of voices and images challenges the "distribution of the sensible", of what is socially, culturally, and politically acceptable to see, hear, 
and think (Rancière, 2004). We witness both the domination and the "emancipation though the bodily positions and movements, functions of speech, the parceling out of the visible and the invisible" (Rancière, 2004: p. 19). As the drone passes over the protestors in the street, the performance suggests the emergence of a "new humanity" (Rancière, 2004: p. 17). Equally important to note is that throughout the filming of the protest, the editors are attentive to the aesthetic concerns. The drone footage jumps and startles from cut to cut provoking an emotional suspense and dramatic effect as the numbers progress from 1 to 43. Rexiste producers are quite aware of the political communicative effect of its content that will be posted, liked, tweeted, and shared across myriad social media platforms and global networks (Bennet \& Segerberg, 2012; Gerbaudo, 2012; Papacharissi, 2014), The viewer does not have to ask what the Rexiste Collective wants, what it demands (Mitchell, 2005). Posters hanging throughout Mexico City as seen in Figure 9, remind people that Saúl Bruno García as well as 42 other young boys are still missing. The message is quite clear: ES HORA A CAMBIARLO TODO.

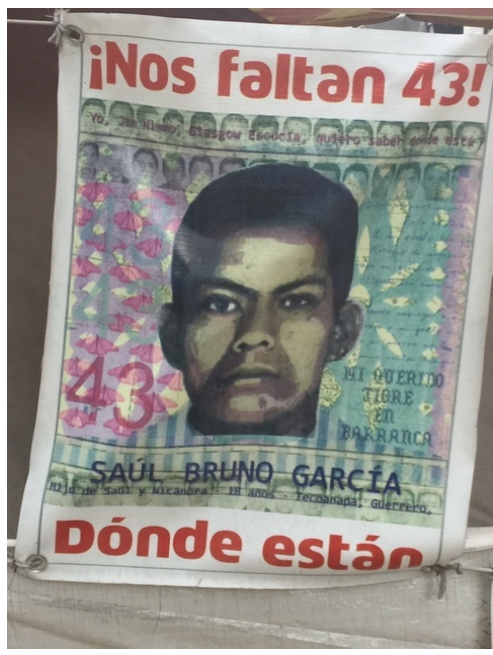

Figure 9. Disappeared student Saúl bruno García.

\section{Conclusion}

In all these phygital performances, we witness collective action frames calling on its viewers to "change everything" (Snow, 2004). At the vanguard of Drone Performance Art, Rexiste has altered the architecture of graffiti art by intervening in the public sphere by deploying digital drone technologies to urge the public " $a$ cambiar todo". The urgency to change the status quo has a cultural "resonance" and power geared to an audience who is willing to listen (Snow \& Bedford, 1988; Williams \& Kubal, 1999). Communicative digital solidarity and connectivity in the form of social media platforms-blogs, vlogs, tweets, posts and shares-allow a form of co-presence, co-location, co-witness, and co-protest without the need for physical presence in real time (Pink et al., 2016). Droncita artistic activism mobilizes people across geographic locations by crafting symbolic rhetorical 
frames such as "YoSoy43" resistance", "Hack the Power", LA FECSM SOMOS TODOS" and "FALTAN", as well as others to demand urgent intervention (de Certeau, 1984; Ginsburg, 1993, 2002; Hebdige, 1979). In so doing, it produces "glocalities" and imagined networked communities of solidarity (Appadurai, 2011). The transmission of drone images of protestors, of former President Peña Nieto, of blood, and of the ever present number 43 produces geographies of pain, suffering and anger across "large cultural distances" (Appadurai, 2011). In these performances, spectators are called on to investigate the record, "to think again", and to take a "moral position" of the events leading to the disappearances of the 43 (Danchev, 2015: p. 196).

In this essay, I have demonstrated how surveillance technologies have been refocused and redeployed as an aesthetic genre of political activism and performance to challenge dominant discourses on militarized power and discipline and to elicit discussions on the risks posed by surveillance technologies in socio-political and domestic spheres. More importantly, I have provided some sense of understanding of Mexico's complex system of interconnected networks vying for control of resources and power. It is not simple. Bandas criminales, transnational crime organizations, drug cartels, government, and nongovernment actors have all played a role in the disappearance of thousands of people-including the Ayotinzapa 43. I have shown how phygital graffiti artists and activists have responded in collective protest to a violent culture of corruption that operates with impunity. Droncita Rexiste represents an emerging art form combining drone technology and the ethical and subversive aesthetics of graffiti street art to offer a new model of testimony, witness, and political participation.

The Ayotinzapa 43 disappeared are still missing. Droncita artists have now implicated you in the disappearance and calls on you to question: "Where are they?"

Now, that you know their story, will you too demand answers?

\section{Conflicts of Interest}

The author declares no conflicts of interest regarding the publication of this paper.

\section{References}

Amnesty International (2019, February 18). Spyware Firm Buyout Reaffirms Urgent Need for Justice for Targeted Activists.

https://www.amnesty.org/en/latest/news/2019/02/spyware-firm-buyout-reaffirms-urge nt-need-for-justice-for-targeted-activists/

Andreas, P. (2017). Myths and Realities of Transnational Organized Crime. Brink: The Edge of Risk.

http://www.brinknews.com/myths-and-realities-of-transnational-organized-crime/

Appadurai, A. (1996). Modernity at Large. Minneapolis, MN: University of Minnesota Press. 
Appadurai, A. (2011). How Histories Make Geographies. Transcultural Studies, 1, 4-13.

Bauman, R., \& Briggs, C. (1990). Poetics and Performance as Critical Perspectives on Language and Social Life. Annual Review of Anthropology, 19, 59-88.

https://doi.org/10.1146/annurev.an.19.100190.000423

Beittel, S. J. (2018). Mexico: Organized Crime and Drug Trafficking Organizations. Congressional Research Service.

Benjamin, W. (1999). The Arcades Project. Boston, MA: Harvard University Press.

Bennet, W. L., \& Segerberg, A. (2012). The Logic of Connective Action. Information, Communication and Society, 15, 739-768.

https://doi.org/10.1080/1369118X.2012.670661

Beverly, J. (2004). Testimonio: On the Politics of Truth. Minneapolis, MN: University of Minnesota Press.

Bishop, C. (2006). The Social Turn: Collaboration and Its Discontents. Artforum, 44, 179-185.

Broner, T. T. (2018). A Stark Reminder of Mexico’s Disappearances Crisis. Human Right Watch.

https://www.hrw.org/news/2018/02/06/stark-reminder-mexicos-disappearances-crisis

Buck-Morss, S. (1992). Aesthetics and Anaesthetics: Walter Benjamin's Artwork Essay Reconsidered. October, 62, 3-41. https://doi.org/10.2307/778700

Carlsen, L. (2015). Tlatyaya Massacre and U. S. Military Aid. American Friends Service Committee.

Castle, T. (1995). The Female Thermometer: Eighteenth-Century Culture and the Invention of the Uncanny. New York: Oxford University Press.

Chamayou, G. (2014). A Theory of the Drone (Lloyd, J., Trans.). New York: The New Press.

Cohen, M. (1999). Profane Illumination: Walter Benjamin and the Paris of Surrealist Revolution. Berkeley, CA: University of California Press.

Critical Art Ensemble (1996). Electronic Civil Disobedience, and Other Unpopular Ideas. Autonomedia.

C-SPAN (1989). Presidential Address on National Drug Policy. https://www.c-span.org/video/?8921-1/president-bush-address-national-drug-policy

Danchev, A. (2015). Our Brothers' Keeper: Moral Witness. Alternatives: Global, Local Political, 40, 191-200. https://doi.org/10.1177/0304375415617623

Davis, J. H. (2018). Trump Calls Some Unauthorized Immigrants "Animals" in Rant. NY Times.

de Certeau, M. (1984). The Practice of Everyday Life. Berkeley, CA: University of California Press.

Dufton, E. (2012). The War on Drugs: How President Nixon Tied Addiction to Crime. The Atlantic.

Duncombe, S. (2016). Affect and Effect: Artful Protest and Political Impact. In H. K. Nielsen (Ed.), The Democratic Public Sphere. Aarhus: Aarhus University Press.

Elkins, J. (1999). What Painting Is: How to Think about the Oil Painting, Using the Language of Alchemy. London: Routledge.

Fairclough, N. (1992). Discourse and Text: Linguistic and Intertextual Analysis within Discourse Analysis. Discourse \& Society, 3, 193-217.

https://doi.org/10.1177/0957926592003002004 
Fernando de Castro, R. (2015). How Mexico Is Becoming the Drone Capital of Latin America. Splinter.

Fiegel, B. (2017). Narco-Drones: A New Way to Transport Drugs. Small Wars Journal. http://smallwarsjournal.com/jrnl/art/narco-drones-a-new-way-to-transport-drugs

Gerbaudo, P. (2012). Tweets and the Streets: Social Media and Contemporary Activism. London: Pluto Press.

Ginsburg, F. (1993). Embedded Aesthetics: Creating a Discursive Space for Indigenous Media. Cultural Anthropology, 9, 365-382. https://doi.org/10.1525/can.1994.9.3.02a00080

Ginsburg, F. (2002). Screen Memories: Resignifying the Traditional in Indigenous Media. In F. Ginsburg, L. Abu-Lughod, \& B. Larkin (Eds.), Media Worlds: Anthropology on the New Terrain (pp. 39-57). Berkeley, CA: University of California Press. https://doi.org/10.1525/9780520928169

Giraldo, C. M. (2014). Mexico’s Cartels Building Custom-Made Narco Drones: DEA. http://www.insightcrime.org/news-briefs/mexico-s-cartels-building-custom-made-narc o-drones-dea

Gramscian, A. (1971). Selections from the Prison Notebooks of Antonio Gramsci. New York: International Publishers.

Groys, B. (2014). On Art Activism. E-Flux Journal, No. 56. https://www.e-flux.com/journal/56/60343/on-art-activism/

Hebdige, D. (1979). Subculture: The Meaning of Style. London: Routledge.

Heywood, A. (1994). Political Ideas and Concepts: An Introduction. London: Macmillan.

Kimball, T. (2016). The One Thing Walls Can't Stop. Motherboard/Vice. https://motherboard.vice.com/en_us/article/3dakkb/walls-cant-stop-creativity-border-1 ines

Kryt, J. (2017). Game of Drones: Mexico's Cartels Have a Deadly New Weapon. Daily Beast.

https://www.thedailybeast.com/game-of-drones-mexicos-cartels-have-a-deadly-new-w eapon

Lind, M. (2007). The Collaborative Turn. In J. Billing, M. Lind, \& L. Nilsson (Eds.), Taking the Matter into Common Hands: On Contemporary Art and Collaborative Practices (pp. 15-31). London: Black Dog Publishing.

Lindekilde, L. (2014). Discourse and Frame Analysis: In-Depth Analysis of Qualitative Data in Social Movement Research. In D. della Porta (Ed.), Methodological Practices in Social Movement Research (pp. 195-227). London: Oxford University Press. https://doi.org/10.1093/acprof:oso/9780198719571.003.0009

Manwaring, M. G. (2012). Gang and TCO Activity in Mexico: Should the U.S. Be Concerned. E-International Relations.

Margalit, A. (2004). The Ethics of Memory. Cambridge, MA: Harvard University Press.

Martinez, M. (2018). Mexico’s López Obrador pledges "Radical” Change. BBC.

Marx, G. (1985). The Surveillance Society: The Threat of 1984-Style Techniques. Futurist, 19, 21-26.

Mazzetti, M. (2012). The Drone Zone. New York Times. http://www.nytimes.com/2012/07/08/magazine/the-drone-zone.html

Meyrowitz, J. (2005). The Rise of Glocality: New Sense of Place and Identity in the Global Village. In K. Nyiri (Ed.), A Sense of Place: The Global and the Local in Mobile Communication (pp. 21-30). Vienna: Passagen. 
Michel, A. H. (2015). Custom Border Protection Drones. Annandale-On-Hudson, NY: Center for the Study of the Drone, Bard College.

Mitchell, W. J. T. (2005). What Do Pictures Want? The Lives and Loves of Images. London: University of Chicago Press. https://doi.org/10.7208/chicago/9780226245904.001.0001

Morrison, E. (2016). Discipline and Desire: Surveillance Technologies in Performance. Ann Arbor, MI: University of Michigan Press. https://doi.org/10.3998/mpub.6944908

Moscoso, E. (2003). Vigilantes to Patrol Border. Ocala.com.

Mouffe, C. (2007). Artistic Activism and Agonistic Spaces. Art \& Research, 1. http://www.artandresearch.org.uk/v1n2/mouffe.html

Neal, M. (2014). Cartels Are Reportedly Building DIY Drones to Fly Drugs over the Border. Motherboard.

Nietzsche, F. (1968). The Will to Power (Trans. Walter Kaufmann and R. J. Hollingdale). New York: Vintage.

Nugent, C. (2018). Mexico Is Suffering Its Bloodiest Year in Modern History. Time Magazine.

O'Grady, S. (2018). Investigators Found 168 Skulls in a Mass Grave in Mexico. They're Part of a National Nightmare. Washington Post. https://www.washingtonpost.com/world/2018/09/07/investigators-found-skulls-mass-g $\underline{\text { rave-mexico-theyre-part-national-nightmare/?utm_term }=.132 \mathrm{~b} 0 \mathrm{~b} 3 \mathrm{e} 3784}$

Omedo, N. (2018). Armed Drones Are Becoming Mexican Cartels' Weapon of Choice. Citizen Truth.

Papacharissi, Z. (2014). Affective Publics: Sentiment, Technology and Politics. Oxford: Oxford University Press. https://doi.org/10.1093/acprof:oso/9780199999736.001.0001

Pensky, M. (2004). Method and Time. In D. Ferris (Ed.), The Cambridge Companion to Walter Benjamin (pp. 177-198). Cambridge: Cambridge University Press. https://doi.org/10.1017/CCOL0521793297.010

Pink, S., Horst, H., Postill, J., Hjorth, L., Lewis, T., \& Tacchi, J. (2016). Digital Ethnography. Principles and Practice. Los Angeles, CA: Sage.

Postil, J. (2011). Localizing the Internet: An Anthropological Account. Oxford: Berghahn.

Rampell, C. (2019). If We're Going to Waste Billions on a Wall, Let Those Billions Be Trump's. Washington Post.

Rancière, J. (2004). The Politics of Aesthetics: The Distribution of the Sensible. London: Continuum.

Rexiste (2014, October 27). Hack the Power. https://www.youtube.com/watch?v=XcL1_9Nzmts\&list=PLvAtPYnbUvsTPkFSULZOT 0JOBKtkarWRR\&index $=5$

Rexiste (2015a, September 24). Es hora de cambiarlo todo: Primer drone grafitero en México.

https://www.youtube.com/watch?v=UqU2MN9UQEo\&list=PLvAtPYnbUvsTPkFSULZ OT0JOBKtkarWRR\&index $=1+$ pena + nieto

Rexiste (2015b, October 4). Así se veía el Zócalo antes de iniciar "Los Juegos del Hambre". https://www.youtube.com/watch?v=dnNpSsF0wDM

Roach, J. (1996). Cities of the Dead: Circum Atlantic Performance. New York: Columbia University Press.

Sanchez, A. (2015). Worst Case Scenario: The Criminal Use of Drones. Council on Hemispheric Affairs. 
http://www.coha.org/worst-case-scenario-the-criminal-use-of-drones/

Seelke, C., \& Finklea, K. (2017). US-Mexican Security Cooperation: The Mérida Initiative and Beyond. Congressional Research Service.

Shaw, I., \& Akhtar, M. (2012). The Unbearable Humanness of Drone Warfare in FATA, Pakistan. Antipode, 44, 1490-1509. https://doi.org/10.1111/j.1467-8330.2011.00940.x

Silverman, K. (1996). The Threshold of the Visible World. New York: Routledge.

Snow, A. (2004). Framing Processes, Ideology, and Discursive Fields. In D. Snow, S. Soule, \& H. Kriesi (Eds.), The Blackwell Companion to Social Movements (pp. 380-412). Oxford: Blackwell Publishing. https://doi.org/10.1002/9780470999103

Snow, A., \& Bedford, R. (1988). Ideology, Frame Resonance, and Participant Mobilization. International Social Movement Research, 1, 197-218.

Snow, D. A., \& Soule, S. A. (2010). A Primer on Social Movements. New York: W. W. Norton.

St. Amant, K., Sapienza, F., \& Sides, C. (2017). Culture, Communication and Cyberspace: Rethinking Technical Communication for International Online Environments. London: Routledge. https://doi.org/10.4324/9781315224848

Strauss, L. D. (2013). The Documentary Debate: Aesthetic or Anesthetic. In D. L. Strauss (Ed.), Between the Eyes. New York: Aperture.

Taylor, D. (1997). Disappearing Acts: Spectacles of Gender and Nationalism in Argentina's "Dirty War". Durham: Duke University Press. https://doi.org/10.2307/j.ctv11smxf9

Taylor, D. (2003). The Archive and the Repertoire: Performing Memory in the Americas. Durham: Duke University Press. https://doi.org/10.1515/9780822385318

The Merida Initiative (2008). U.S. Embassy \& Consulates in Mexico. https://mx.usembassy.gov/our-relationship/policy-history/the-merida-initiative/

Tsipori, T. (2009). UAV Maker Aeronautics to Supply Mexican Police. Globes Israel's Business Leader. https://en.globes.co.il/en/article-1000425962

Tufekci, Z. (2017). Twitter and Tear Gas: The Power and Fragility of Networked Protest. New Haven, CT: Yale University Press.

Turner, V. W. (1987). The Anthropology of Performance. New York: PAJ Publications.

Vice (2014). The Missing 43: Mexico's Disappeared Students. https://www.youtube.com/watch?v=0jt-urgNN3A

Wang, Y. (2016). As China's Drone Market Takes off, Leader DJI Still Flies Far above the Competition. Forbes.

https://www.forbes.com/sites/ywang/2016/05/12/chinas-flood-of-cheap-flying-cameras -is-little-threat-to-dajiang/

Webb, W. (2017). Israel Aiding Mexico's Development with More Arms, Drones, and Spy Software. MFN News.

Williams, R. (2004). The Cultural Contexts of Collective Action: Constraints, Opportunities, and the Symbolic Life of Social Movements. In D. Snow, S. Soule, \& H. Kriesi (Eds.), The Blackwell Companion to Social Movements (pp. 91-115). Oxford: Blackwell Publishing.

Williams, R., \& Kubal, J. (1999). Movement Frames and the Cultural Environment: Resonance, Failure and the Boundaries of the Legitimate. Research in Social Movements, Conflicts and Change, 21, 225-248. 